ISSN: 2224-0616

Int. J. Agril. Res. Innov. \& Tech. 6 (2): 82-86, December, 2016 Available online at http:// www.ijarit.webs.com

\title{
IMPACT OF SUBSTRATE ON SOILLESS TOMATO CULTIVATION
}

\author{
T.P. Suvo ${ }^{1 *}$, H. Biswas ${ }^{1}$, M.H. Jewel ${ }^{2}$, M.S. Islam ${ }^{3}$ and M.S.I. Khan ${ }^{4}$
}

Received 30 October 2016, Revised 12 December 2016, Accepted 27 December 2016, Published online 31 December 2016

\begin{abstract}
An experiment was carried out to determine the effect of four different media based hydroponics on plant growth, yield and nutritional values at Biochemistry laboratory of Patuakhali Science and Technology University (PSTU), Bangladesh during November 2014 to April 2015. Tomato plants were grown in closed soilless system where Hoagland solution as nutrient solution and jute fiber, cotton (jhut), coconut husk as substrate. Among four types of media, the media composed with Hoagland solution and jute fiber showed good impact on growth and nutritional values than the other three media (media of Hoagland solution with coconut husk, Hoagland solution with cotton and only Hoagland solution. It was revealed that the highest plant height, yield, vitamin $\mathrm{C}$, fruit protein, fat and fiber content of all were related to media combination of jute fiber and Hoagland solution. Among all the verities, the highest plant height $(106 \mathrm{~cm})$, yield $(5.3 \mathrm{~kg}$ plant-1), fruit Vitamin C content (64.54 mg $\left.100 \mathrm{~g}^{-1}\right)$, fruit protein (17.67\%), fat (5.2\%) and fiber (7.9\%) content was recorded from Patharkuchi tomato variety.
\end{abstract}

Keywords: Hydroponics, Tomato, Substrate, Vitamin C, Protein, Fat, Fiber

${ }^{1}$ Department of Biochemistry And Food Analysis,, Patuakhali Science and Technology University, Patuakhali-8602,
Bangladesh.
${ }^{2}$ Department of Agronomy, Bangladesh Agricultural University, Mymensingh-2202, Bangladesh.
${ }^{3}$ Department of Post-harvest Technology and Marketing, Patuakhali Science and Technology University, Patuakhali-8602,
Bangladesh.
${ }^{4}$ Department of Food Microbiology, Patuakhali Science and Technology University, Patuakhali-8602, Bangladesh.
*Corresponding author's email: shuvopatra@gmail.com (T.P. Suvo)

\section{Introduction}

Good control over environment while cultivation of plant gives good growth and development of it. Soilless cultivation allows that scope and now practiced all over the world (VanOs and Benoit, 1999; VanOs, 2002). Cultivation of plant without soil gives more products in less time, allows to growing plant more densely with balanced supply of air, water and nutrient where the products are more resistant to diseases and natural or biological control can be easily employed to it. Moreover, soil born pests and diseases can be easily eliminated through the soilless cultivation. Especially for the container mobility the pests and diseases are easier to get rid where we useless fertilizer and pesticide. Troublesome weeds can be avoided by this cultivation (Munoz, 2010). A number of substrates are used in hydroponics cultivation like saw dust, coconut fiber, oasis cubes, sphagnum peat moss, rice hulls, polyurethane, grow slabs, clay bricks, lava rocks, LECA etc. A good substrate should have adequate mechanical properties, high porosity, ability to distribute consistent oxygen and water for activity, low soluble salt content with a $\mathrm{pH}$ between 5.0 to 6.5 and should be sterile and chemically inert (Yeager et al., 2007). Soilless substrate originated from organic materials which would improve the product quality with health substance (Donnan, 1998). Tomato is a vegetable which is cultivated all over the world and a good source of Vitamin C, biotin, molybdenum, vitamin $\mathrm{K}$ and also a good source of copper, potassium, manganese, dietary fiber, vitamin A, B6, and E. Additionally, they are a good source of chromium, pantothenic acid, protein, zinc and iron. Tomatoes provided a unique variety of phytonutrients included carotenoids, flavonoids, glucosides and fatty acid derivatives. Vitamin $\mathrm{C}$ is water soluble and essential for our normal growth and tissues in all parts of our body. Vitamin C content in hydroponically grown fruit is higher than that of conventional tomatoes (Hallmann, 2003). This growing system also influence the nutritional value and phenolic compound content in tomato (Hallmann, 2012) and a study showed that hydroponically grown tomato had higher ratio of organic acids, total flavonoids, 3-quercetion rutinoside, quercetion-3-O-glucoside, chlorogenic acid and kaempferol content than the 
conventional fruit. Starting from the above consideration, our aim was to evaluate the impact of substrate on soilless tomato cultivation.

\section{Materials and Methods}

In present study, the effects of substrate on tomato plant growth and nutritional values were investigated. The experiment was conducted at Biochemistry Laboratory, Patuakhali Science and Technology University, Dumki, Patuakhali, Bangladesh $\left(22^{\circ} 37^{\prime} \mathrm{N}\right.$ latitude and $89^{\circ} 10^{\prime} \mathrm{E}$ longitude).

\section{Nutrient solution and soilless media}

The nutrient solution was prepared according to the method described by Hoagland and Arnon (1950) with modification necessitated to the experiment. Non-reactive plastic pot (3.0 litter) was used for nutrient media preparation where jute fiber, coco fiber, cotton was used as substrate. All substrates were supplied with same nutrient composition. The nutrient media were considered as treatments of the experiment where four types of media used that was T1 (Hoagland solution with well deride jute fiber), T2 (Hoagland solution with coconut fiber), T3 (Hoagland solution with cotton) and T4 (only Hoagland solution) when jute fiber, coconut fiber and cotton fiber were used as substrate.

\section{Plant materials and growth conditions}

Five different tomato varieties (three Bangladeshi variants named Ratan, Roma VF , Ratan HYV and two Indian varieties named Patharkuchi, Pusharubi) were used as plant material. Seedbed was prepared using 50\% sand, 25\% ash and $25 \%$ topsoil (the outmost layer of soil, usually the top 2-8 inches). On 10 November 2014, the seed was sown 1 inch's depth in seedbed. At the two true leaf stages, tomato plants were transplanted into nutrient media. Plants were grown in open place with direct sunlight $(11 \pm 1$ hour's photoperiod) and $21 \pm 2{ }^{\circ} \mathrm{C}$ temperature.

\section{Irrigation and fertigation}

For soilless culture, constant volume of the nutrient solution was maintained by adding deionized distilled water every day. Nutrient level was maintained by adding fresh nutrient solution by every 3 days. Air pump was used for water oxygenation. Constant volume of the nutrient solution was maintained by adding distilled water every day. Nutrient level was maintained by adding fresh nutrient solution by every 5 days. Air pump was used for water oxygenation.

\section{Analytical methods}

Ascorbic acid was determined according to the dye method by Ranganna (1977). The nitrogen concentration in plant tissues (leaves, stems, fruits and flowers) was determined after mineralization with sulfuric acid by "Regular Kjeldahl method" (Bremner, 1965) and used the conversion factor to determine the protein content from nitrogen content. The determination of fat and fibre was done using methods in Association of Official Analytical Chemists (AOAC, 1990).

\section{Data analysis}

All data were statistically analyzed by ANOVA using the SPSS software package (SPSS 16 for Windows, 2007). Duncan's Multiple Range test was performed at $\mathrm{P} \leq 0.05$ on each of the significant variables measured.

\section{Results and Discussion}

\section{Plant height and number of flowers}

The plant height and number of flowers of tomato varieties in jute fiber treatment was significantly higher than plants grown on other treatments. Among all the variety, variety named Patharkuchi shows highest plant height in jute fiber treatments (T1). Plants grown on cotton fiber (T3) treatments shows poor growth where the plants grown on control (only nutrient solution) shows good height (Table 1).

In case of number of flowers of tomato plants, the highest number was related to the plants grown on jute fiber treatments (T1) (Table 2).

Table 1. Plant height (cm) of different tomato varieties grown on four soilless media.

\begin{tabular}{lccccc}
\hline Treatments & \multicolumn{5}{c}{ Tomato varieties } \\
\cline { 2 - 5 } (substrate) & Ratan & Roma VF & Pusharubi & Ratan HYV & Patharkuchi \\
\cline { 2 - 5 } & & Plant height $(\mathrm{cm})$ \\
\hline T 1(Jute fiber) & $75^{\mathrm{a}}$ & $81.9^{\mathrm{a}}$ & $76.76^{\mathrm{a}}$ & $76.39^{\mathrm{ab}}$ & $106^{\mathrm{a}}$ \\
T 2 (Coco fiber) & $64.87^{\mathrm{b}}$ & $72.6^{\mathrm{b}}$ & $73.94^{\mathrm{a}}$ & $85.64^{\mathrm{a}}$ & $82.33^{\mathrm{c}}$ \\
T 3 (Cotton fiber) & $47.04^{\mathrm{c}}$ & $47.08^{\mathrm{c}}$ & $46.23^{\mathrm{b}}$ & $50.9^{\mathrm{c}}$ & $50.8^{\mathrm{d}}$ \\
T 4 (Control) & $64.9^{\mathrm{b}}$ & $67.43^{\mathrm{b}}$ & $73.57^{\mathrm{a}}$ & $74.00^{\mathrm{b}}$ & $91.98^{\mathrm{b}}$ \\
\hline
\end{tabular}

Values are the mean of four replicate samples; In each column, values followed by the same letter do not differ significantly at $\mathrm{P}=0.05$. 
Table 2. Number of flowers at 70 days after transplanting of different tomato varieties grown on four soilless media.

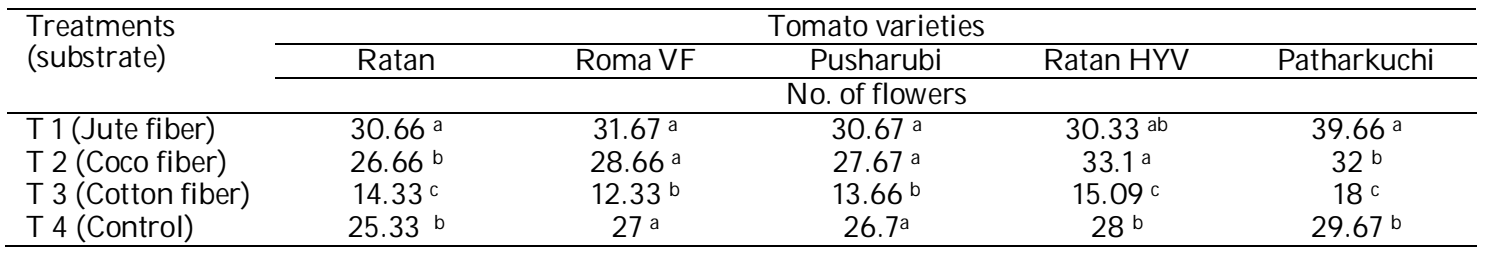

Values are the mean of four replicate samples; In each column, values followed by the same letter do not differ significantly at $\mathrm{P}=0.05$.

\section{Total y ield}

Total amount of yield of plants grown on jute fiber treatment was significantly higher by 28,86 and $37 \%$ compare to coco fiber (T2), cotton fiber (T3) and control (T4), respectively (Table 3). The highest yield (5.31 kg plant-1) recorded from Patharkuchi variety was higher than the value reported by Tzortzakis and Economakis (2005) for tomato plant $(4.4 \mathrm{~kg}$ plant-1). The total amount of yield obtained from Roma VF was satisfactory. Lower amount of yield was recorded from the plants of cotton fiber treatment (T3). It may be related to the physical and chemical properties of substrate and the response of plant was not good because of coloring and toxic chemicals of cotton, which changed the character of Hoagland solution and inhabited the nutrient uptake by the plants.

Table 3. Total amount of yield ( $\mathrm{kg}_{\text {plant }}{ }^{-1}$ ) of different tomato varieties grown on four soilless media.

\begin{tabular}{lccccc}
\hline Treatments & \multicolumn{5}{c}{ Tomato varieties } \\
\cline { 2 - 6 } (Substrate) & Ratan & Roma VF & Pusharubi & Ratan HYV & Patharkuchi \\
\cline { 2 - 5 } & & \multicolumn{5}{c}{ Yield (kg/plant) } \\
\hline T 1 (Jute fiber) & $3.09^{\mathrm{a}}$ & $4.72^{\mathrm{a}}$ & $1.72^{\mathrm{a}}$ & $2.42^{\mathrm{a}}$ & $5.31^{\mathrm{a}}$ \\
T 2 (Coco fiber) & $1.73^{\mathrm{b}}$ & $4.5^{\mathrm{a}}$ & $1.47^{\mathrm{ab}}$ & $2.51^{\mathrm{a}}$ & $2.28^{\mathrm{b}}$ \\
T 3 (Cotton fiber) & $0.51^{\mathrm{c}}$ & $0.39^{\mathrm{b}}$ & $0.38^{\mathrm{c}}$ & $0.53^{\mathrm{b}}$ & $0.75^{\mathrm{c}}$ \\
T 4 (Control) & $1.53^{\mathrm{b}}$ & $4.31^{\mathrm{a}}$ & $1.12^{\mathrm{b}}$ & $1.94^{\mathrm{a}}$ & $2.12^{\mathrm{b}}$ \\
\hline
\end{tabular}

Values are the mean of four replicate samples; In each column, values followed by the same letter do not differ significantly at $\mathrm{P}=0.05$.

Most of the flowers were dried up and fell off or they might form tiny fruits, which shriveled up and fall off without further development. This may be due to their genetic composition. Adelana (1976) discovered that only $50 \%$ of the flowers produced developed into fruits, thus sink size was a limiting factor to fruit production in tomato. The poor fruit set may be because of high temperatures that are not conducive for good fruit set (Simon and Sobulo, 1974). The varietals differences in growth and yield might be attributed to the differences in ecological distribution of the tomato varieties (Olaniyi, 2007). The variation in yield may also be due to genetic differences among the varieties since they were grown under the same environ-mental conditions (Olaniyi and Fagbayide, 1999).

\section{Ascorbic acid content}

Fruit ascorbic acid content of plants grown on jute fiber treatment (T1) were significantly higher by 25,55 and $40 \%$ compared to coco fiber, cotton fiber and control treatments. Highest amount of ascorbic acid (64.54 mg $100 \mathrm{~g}^{1}$ ) were obtained from the variety Patharkuchi and related to T1 treatment (Table 4). This value was higher than the value reported by Tzortzakis and Economakis (2005) for tomato fruit ascorbic acid content (20 $\left.\operatorname{mg} 100 \mathrm{~g}^{-1}\right)$.

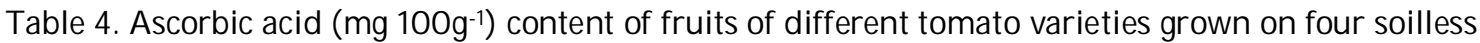
media.

\begin{tabular}{lccccc}
\hline Treatments & \multicolumn{5}{c}{ Tomato varieties } \\
\cline { 2 - 5 } (Substrate) & Ratan & Roma VF & Pusharubi & Ratan HYV & Patharkuchi \\
\cline { 2 - 5 } & & \multicolumn{4}{c}{ Ascorbic acid (mg/ 100g) } \\
\hline T 1 (Jute fiber) & $35.83^{\mathrm{a}}$ & $34.16^{\mathrm{a}}$ & $41.67^{\mathrm{a}}$ & $50.62^{\mathrm{a}}$ & $64.54^{\mathrm{a}}$ \\
T 2 (Coco fiber) & $29.37^{\mathrm{b}}$ & $24.58^{\mathrm{b}}$ & $28.95^{\mathrm{b}}$ & $42.08^{\mathrm{b}}$ & $44.79^{\mathrm{b}}$ \\
T 3 (Cotton fiber) & $13.5^{\mathrm{c}}$ & $15.1^{\mathrm{c}}$ & $17.91^{\mathrm{c}}$ & $22.29^{\mathrm{d}}$ & $34.58^{\mathrm{c}}$ \\
T 4 (Control) & $26.04^{\mathrm{b}}$ & $22.08^{\mathrm{b}}$ & $24.03^{\mathrm{bc}}$ & $29.16^{\mathrm{c}}$ & $31.66^{\mathrm{c}}$ \\
\hline
\end{tabular}

Values are the mean of four replicate samples; In each column, values followed by the same letter do not differ significantly at $\mathrm{P}=0.05$. 


\section{Protein, fat and fiber content}

The significant difference among the treatments and variety for protein, fat and fiber content of fruits was observed. Highest amount of protein (17.67 \%), fat (5.2\%) and fiber (7.9\%) was recorded on jute fiber treatment. The variation in the nutritive values of different varieties of tomato used in this study might be due to the environmental and treatments effect in which they are grown (Table 5-7).

Table 5. Protein content (\%) of fruits of different tomato varieties grown on four soilless media.

\begin{tabular}{lccccc}
\hline Treatments & \multicolumn{5}{c}{ Tomato varieties } \\
\cline { 2 - 5 } (Substrate) & Ratan & Roma VF & Pusharubi & Ratan HYV & Patharkuchi \\
\cline { 2 - 5 } & & \multicolumn{5}{c}{ Protein content (\%) } \\
\hline T 1 (Jute fiber) & $16.21^{\mathrm{a}}$ & $14.05^{\mathrm{a}}$ & $15.07^{\mathrm{a}}$ & $16.97^{\mathrm{a}}$ & $17.67^{\mathrm{a}}$ \\
T 2 (Coco fiber) & $10.38^{\mathrm{b}}$ & $9.04^{\mathrm{b}}$ & $13.12^{\mathrm{b}}$ & $13.92^{\mathrm{b}}$ & $15.98^{\mathrm{a}}$ \\
T 3 (Cotton fiber) & $8.39^{\mathrm{c}}$ & $7.14^{\mathrm{b}}$ & $9.74^{\mathrm{c}}$ & $9.65^{\mathrm{c}}$ & $10.32^{\mathrm{b}}$ \\
T 4 (Control) & $10.32^{\mathrm{b}}$ & $8.4^{\mathrm{b}}$ & $10.55^{\mathrm{c}}$ & $9.39^{\mathrm{c}}$ & $10.87^{\mathrm{b}}$ \\
\hline
\end{tabular}

Values are the mean of four replicate samples; In each column, values followed by the same letter do not differ significantly at $\mathrm{P}=0.05$.

Table 6. Fat content (\%) of fruits of different tomato varieties grown on four soilless media.

\begin{tabular}{|c|c|c|c|c|c|}
\hline \multirow{3}{*}{$\begin{array}{l}\text { Treatments } \\
\text { (Substrate) }\end{array}$} & \multicolumn{5}{|c|}{ Tomato varieties } \\
\hline & Ratan & Roma VF & Pusharubi & Ratan HYV & Patharkuchi \\
\hline & & & \% Fat & & \\
\hline T 1(Jute fiber) & $3.72^{b}$ & $4.22^{a}$ & $4.08^{a}$ & $4.91^{\mathrm{a}}$ & $5.2^{\mathrm{a}}$ \\
\hline T 2 (Coco fiber) & $3.67^{c}$ & $3.86^{b}$ & $4.2^{\mathrm{a}}$ & $3.1^{\mathrm{c}}$ & $4.7^{b}$ \\
\hline T 3 (Cotton fiber) & $2.8^{d}$ & $3.1^{d}$ & $2.13^{d}$ & $2.3^{d}$ & $3.7^{d}$ \\
\hline T 4 (Control) & 3.78 a & $3.6^{c}$ & $3.21^{c}$ & $4.7^{b}$ & $4.6^{c}$ \\
\hline
\end{tabular}

Values are the mean of four replicate samples; In each column, values followed by the same letter do not differ significantly at $\mathrm{P}=0.05$.

Table 7. Fiber content (\%) of fruits of different tomato varieties grown on four soilless media.

\begin{tabular}{lccccc}
\hline Treatments & \multicolumn{5}{c}{ Tomato varieties } \\
\cline { 2 - 5 } (Substrate) & Ratan & Roma VF & Pusharubi & Ratan HYV & Patharkuchi \\
\cline { 2 - 5 } & & & \% Fiber & \\
\hline T 1 (Jute fiber) & $5.3^{\mathrm{a}}$ & $7.3^{\mathrm{a}}$ & $6.3^{\mathrm{a}}$ & $5.5^{\mathrm{a}}$ & $7.9^{\mathrm{a}}$ \\
T 2 (Coco fiber) & $4.6^{\mathrm{b}}$ & $5.1^{\mathrm{c}}$ & $4.2^{\mathrm{c}}$ & $5.2^{\mathrm{b}}$ & $6.6^{\mathrm{b}}$ \\
T 3 (Cotton fiber) & $3.2^{\mathrm{d}}$ & $4.8^{\mathrm{d}}$ & $2.3^{\mathrm{d}}$ & $2.1^{\mathrm{d}}$ & $4.5^{\mathrm{d}}$ \\
T 4 (Control) & $3.7^{\mathrm{c}}$ & $7.2^{\mathrm{b}}$ & $5.9^{\mathrm{b}}$ & $4^{\mathrm{c}}$ & $5.8^{\mathrm{c}}$ \\
\hline
\end{tabular}

Values are the mean of four replicate samples; In each column, values followed by the same letter do not differ significantly at $\mathrm{P}=0.05$.

\section{Conclusion}

It is concluded that the growth and the nutritional values was much more satisfactory for plant grown under media of jute fiber that is T1 treatment. The results also indicate that jute fiber may be ensuring the oxygen and carbon dioxide transport between roots and external air and have the ability to maintain original characteristics during cultivation. The plant grown under media using coconut husk and only solution was good but not good enough like media of jute fiber. In case of cotton media, the response of plant was not good because of coloring and toxic chemicals of cotton, which changed the character of Hoagland solution and inhabited the nutrient uptake by the plants. With the controlled nutrient supply, less expense, less labor, no use of pesticides or fertilizer with controlled environment the use of low cost jute fiber as a substrate with Hoagland solution could be an effective one for growing tomato in Bangladesh. On the other hand, the variety like Patharkuchi and Roma VF showed good growth and production on this subtropical monsoon climate under soilless cultivation than other varieties. The overall effect of the type of substrate on tomato growth and yield in the present experiment suggests that the jute fiber is suitable substrates for tomato soilless cultivation. Further investigation is however needed to compare this substrate with other conventional substrate used in soilless culture. 


\section{References}

Adelana, B.O. 1976. Effect of staking on growth and yield of tomatoes, East African Agril. Forestry J . 41 (3): 243-249.

AOAC, 1990. Official methods of analysis, Association of Official Analytical Chemists, Washington DC. pp. 79-80.

Bremner, J.M. 1965. Total nitrogen. In: Methods of soil analysis, Part 2. Argon. Monographe, 9th Ed., pp. 1149- 78.

Donnan, R. 1998. Hydroponics around the world. Practical Hydroponics and Greenhouses, July/August 1998. pp. 18-25.

Hallmann, E. 2012. The influence of organic and conventional cultivation systems on the nutritional value and content of bioactive compounds in selected tomato types. J. Sci. Food Agric. 92: 2840-2848.

Hallmann, E. 2003. The estimation of crop and quality fruits of selected types of tomato cultivated on mineral rockwool. Ph.D thesis, Department of Horticulture, WULS-SGGW; pp. 8-9.

Hoagland, D.R. and Arnon, D.I. 1950.The waterculture method for growing plants without soil. Calif. Agric. Expt. Sta. Circular no. 374. $34 \mathrm{p}$.

Munoz, H. 2010. Hydroponics Home-Based Vegetable Production System Manual. Institute for Cooperation on Agriculture (IICA). Guyana. http:// www.iica.int.

Olaniyi, J.O. and Fagbayide, J.A. 1999. Performance of eight F1 Hybrid Cabbage (Brassica olerácea L.) varieties in the
Southern Guinea Savanna zone of Nigeria. J . Agric. Biotechnol. Environ. 1: 4-10.

Olaniyi, J.O. 2007. Evaluation of Yield and Quality Performance of Grain Amaranth Varieties in the South western Nigeria Res. J. Agron. 1(2): 42-45.

Ranganna, S. 1977. Manual of Analysis of Fruit and Vegetable Products. 1st Edn., Tata MoGraw-Hill, New Delhi, India. pp.105-106

Simon, J.H. and Sobulo, R.A. 1974. Methods for higher tomato yield in Western State of Nigerian. Paper presented at Institute of Agric. Research Conference. Ibadan, Nigeria. pp. 02-09.

Tzortzakis, N.G. and Economakis, C.D. 2005. Shredded maize stems as an alternative substrate medium: effect on growth, flowering and yield of tomato in soilless culture. J. Veg. Sci. 11: 57- 70.

VanOs, E.A. 2002. Closed soilless growing systems: a sustainable solution for Dutch greenhouse horticulture. Water Sci. Tech. 39: 105- 112.

VanOs, E.A. and Benoit, F. 1999. State of art of the Dutch and Belgian greenhouse horticulture and hydroponics. Acta Hort. 481: 765- 767.

Yeager, T.H., Fare, D., Lea-Cox, J., Ruter, J., Bilderback, T.E., Gilliam, C.H., Niemiera, A.X., Warren, L., Whitwell, T.E., Wright, R.D. and Tilt, K.M. 2007. Best management practices: guide for producing containergrown plants. $2^{\text {nd }}$ ed. Southern Nurserymen's Association, Maretta, GA. pp. 4-10. 